\title{
Suffering in the perspective of God's governance, eschatology and God's council
}

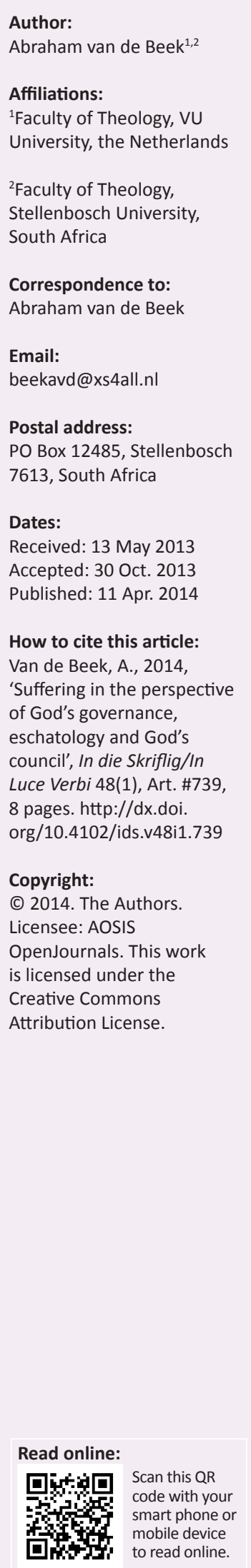

From the beginning of Christian theology, theologians have struggled with the question of how suffering in the world is related to God's providence. A classic response to this question is that, ultimately, God's governance is beyond human understanding. More recently an eschatological solution has been preferred: God is involved in a historical process and he will finally overcome evil. This article argued that both responses have their own problems. In the first God is a hidden mystery, and in the latter either the outcome of history is uncertain or God is waiting unnecessarily long. On the other hand, both provide consolation to human beings in times of suffering. Which one of the two answers is more helpful, depends on culture and context. Therefore, they are both acceptable responses to the question. At a deeper level, one can argue that both refer to eternity - one in a spatial model (above) and the other in a temporal model (hereafter). Both space and time are metaphors in this context. That is also the case when we speak of 'before' with regard to God's eternal council. Ultimately, from a perspective of eternity, God's council, God's governance and God's final judgment coincide. In Christian theology these concepts can only be understood in the paradigm of God's revelation in Christ, who is the expression of the mystery of creation - as is especially indicated in the letters to the Ephesians and Colossians.

Het lijden bezien vanuit Gods bestuur, eschatologie en Gods raad. Vanaf het begin van het Christendom hebben theologen geworsteld met de vraag hoe het lijden in de wereld zich verhoudt tot Gods voorzienigheid. Een klassiek antwoord daarop is dat ten laatste Gods bestuur het menselijk begrip te boven gaat. Tegenwoordig wordt eerder de voorkeur gegeven aan een eschatologische oplossing: God is betrokken in een proces door de geschiedenis waarin Hij uiteindelijk het kwaad zal overwinnen. De auteur betoogt dat beide benaderingen hun eigen problemen hebben. In het eerste geval is God een onkenbaar mysterie en in het tweede geval is de afloop onzeker of wacht God onnodig lang met zijn overwinning. Aan de andere kant bieden beide antwoorden mensen troost in lijdenssituaties. Welke van de twee antwoorden het beste is, hangt af van cultuur en context. Daarom zijn beide aanvaardbaar als antwoord op het probleem van Gods voorzienigheid. Op een dieper niveau kan men betogen dat beide verwijzen naar de eeuwigheid, het eerste antwoord in een ruimtelijk model ('te boven') en het tweede in een tijdsmodel ('hierna'). Zowel ruimte als tijd zijn hier metaforisch gebruikt. Dat is ook het geval als we spreken over 'vóór' met betrekking tot Gods eeuwige raad. Uiteindelijk zijn, vanuit het perspectief van de eeuwigheid, Gods raad, Gods beleid en Gods laatste oordeel identiek. In de christelijke theologie kunnen deze concepten alleen worden verstaan in het paradigma van Gods openbaring in Christus, die de expressie van het geheimenis van de schepping is, zoals met name de brieven aan de Efeziërs en aan de Kolossenzen aangeven.

\section{God's governance}

God's governance is an important topic in classic reformed theology. As regards reformed spirituality, it is not overstated to even claim that it is a core issue. We trust in God. We believe that we are safe in his guidance of our lives. In the ambiguities of life and world history, we know that God is in control (for classic references, see Heppe 1958:201-204, 213-223). Nothing can happen against his will, by which he cares for us as a loving Father. Generations of reformed Christians grew up with the answer of the Heidelberg Catechism (Creeds of Christendom 1563) which providence is:

[...] the almighty and everywhere present power of God, whereby, as it were by his hand, he upholds and governs heaven, earth, and all creatures; so that [...] all things come, not by chance, but by his fatherly hand. (Answer 27)

Those who delved deeper into the basics of reformed theology, found their belief in God's omnipotent governance confirmed in the strong chapters on this issue in Calvin's Institutes (I.16f.).

1.See also Belgic Confession, Article 13 (Creeds of Christendom 1561). 
Both Calvin and his later followers could easily refer to evidence for their theology of God's governance in the Scriptures (cf. Institutes I.16.5-7; Van Genderen \& Velema 1992:289).

Providence gives basic trust to human lives and a deep relation to God, the Father in heaven. This does not mean, however, that this trust is uncontested. The confession of God's providence claims that not only pleasant things come from God, but that shocking experiences also occur according to his will. The Heidelberg Catechism says that 'rain and drought, fruitful and barren years, meat and drink, health and sickness, riches and poverty [...] come [...] by his fatherly hand' (Answer 27). It is easy to believe that happy days are a gift of a caring, divine Father, but believing that severe illness is also given by him, is far more difficult. Nevertheless, it is precisely hardship that gives the confession of divine providence its power: when life runs out of our hands, we can trust that it does not run out of God's hand (cf. Institutes I.17.8-11).

Christians believe that God is in control and they believe in his benevolence. However, they also try to understand why things happen (Institutes I.16.9; I.18.1 \& 3). If God is a caring Father, we hope for insight in the way he leads us, because understanding helps us to continue along the way to which he calls us. Understanding is difficult in times of hardship. Consequently, a vast accumulation of literature on God's guidance amidst confounding experiences has emerged, usually of a theodicean character. We try to understand why God, though being a benevolent Father, gives painful experiences. Many answers are given, and often these provide consolation for people in affliction. However, there are situations where answers fall short. In Adrio König's book titled God, waarom lyk die wêreld so? (2002:32-46), he tells stories so shocking that we cannot believe that what happened to these people is willed by a benevolent God. Anybody who is alert to events in the world can add his or her own stories. What human beings suffer is above understanding; most of all above understanding God's loving care for his creation. Even nature, as God's creation, is beyond human understanding and human control (Singghi 2012:695).

The classic reaction to this enigma is that our understanding falls short, but not God's providence (Institutes I.17.2). Human understanding is too limited to fathom the depth of God's will. So, though we do not understand, we must trust. God knows better than we do. Nobody on earth will understand why a little child was tortured and killed, but in heaven they know. There is a transcendent solution for present immanent unsolvable problems (Institutes I.17.1).

\section{Demanding too much}

According to Calvin (and the Heidelberg Catechism), not only good, but also bad things are ordained by God. The idea that an omnipotent God rules a world in which children are horribly killed, is absolutely unacceptable to many people. If God is in control of such a world, they reject this God. König (2002) cannot cope with Calvin's God:
Óók die kwaad en alle sonde en lyding word deur God beveel as Hy dit so wil. Kom ons konkretiseer dit vir ons tyd. Die moordenaars wat op 11 September 2001 daardie passasiersvliegtuie in Amerika geskaak en daarmee in die Wêreldhandelsentrum in New York en die Pentagon in Washington vasgevlieg het, was volkome onder die beheer van God. As 'n mens Calvyn se siening van God se voorsienigheid konsekwent deurvoer, beteken dit dat God daardie duiwelse gedagte in die terroriste se koppe gesit het. [...] God het ook beskik dat presies die 'regte' mense in die vliegtuie was, en ook die 'regte' mense in die geboue. Klink dit verskriklik? Maar as God alle dinge wat gebeur, voorbeskik, geld dit tog ook alle kwaad en spesifiek alle sonde. [Also the evil and all sin and suffering are commanded by God, if he so wishes. Let us concretise this for our time. The killers that hijacked the passenger planes in America on 11 September 2001 and flew it into the World Trade Centre in New York and the Pentagon in Washington, was completely under the control of God. If one consistently carries through Calvin's view of God's providence, it means that God put those devilish thoughts in the terrorists' minds. [...] God also ordained that exactly the 'right' people were in the aircraft, and the 'right' people were in the buildings. Does that sound awful? But if God foreordains all things that happen, it is also counts for all evil and specifically all sin.] (bl. 65, [author's own translation])

If God has his own hidden aims with anything that happens, 'watter oordeel sou Hy wou voltrek [...] oor die nege maande oue kind wat in Oktober 2001 in die dorpie Louisvale hier in ons land verkrag en gesodomiseer is?' ['what was his aim [...] with the nine-month-old child who was raped and sodomised in October 2001 in the town Louisvale here in our own country?'] (König 2002:68).

König cannot believe in this God - and most people concur with his opinion. Like many others, he rejects 'the God of Calvin' (Hesselink 1997:111).

The conclusions that people draw from their rejection of God's absolute control over human life and world history are diverse. Some keep to the classic definition of God as controlling power, but because they reject such a God, most of these draw the conclusion that such a God does not exist: "'Het enige excuus voor God is dat Hij niet bestaat", menen velen' ['Many people are of the opinion that the only apology for God is that he does not exist'] (Van den Brink \& Van der Kooi 2012:301). The classic model of God's omnipotence can go so far that even the criminal act is provided by God. Only its evil character is excluded from it (Leydecker 1700:II. VI.xxv; cf. Hoek 2013:193). However, how can God provide the act of raping a young girl and slitting her throat without being involved in the evil of such a deed? If there were such an omnipotent God who created this world, it should be impossible for him to deal with his own creation in such a manner, unless he is an ultimately perverse Being. Speaking about God as the almighty Creator is thus impossible for many people, and due to this aporia they have lost their faith.

Others cannot rid themselves of this image of God and keep on fighting against him. Their whole life is just one cry: 'Why?' Why did God act in such a way as they experienced - in the loss of a child, a partner, in the terrible sufferings of 
refugees, war children, raped women and murdered girls? Theology cannot sidestep this problem easily. Is it really possible to believe in an omnipotent God when we see what happens in the world? (cf. Blom 2009).

\section{Redefining God's identity}

Consequently many theologians do not reject God as a caring Father, but they opt for a different definition of God. They reject the idea of God as a controlling power. John Cobb makes this the first rule of his theological system: 'God is not controlling power' (Cobb \& Griffin 1977:9). He is a God who lovingly lures human beings and all existing things to new opportunities. That is the way his governance functions: providing chances and enabling human beings to find their way to the future. This may be a way of trial and error, but it is not God who initiates the failures of our ideals. On the contrary, he provides us continuously with new possibilities so that we never have to despair (Cobb \& Griffin ibid; Cobb 1965).

Other theologians rather focus on God's caring love in hardship. It is not God who brings us in these circumstances. Evil powers try to obstruct God's good and peaceful creation. Still others claim that what happens is just by accident (Kushner 1981). Whatever the cause of our troubles may be, we find God fighting at our side.

Both reactions, being in conflict with a belief in an almighty God whilst keeping the classic definition as well as redefining the concept of God, occur especially in modernity since human beings no longer accept controlling power. Human maturity requires at least a reasonable explanation for the exercise of power. If this cannot be provided, people will revolt against this power. Theologians in this era are challenged to develop theological designs that respond to this human maturity and thus they cannot keep to the classic submission to an incomprehensible Supreme Being. It is precisely this challenge that König (2002) expresses. Theologians must find other ways. Because it is difficult to be both a theologian and an atheist, or to live continuously in conflict with the God whom you confess, they opt for the other track: redefining God's identity.

It conforms to modern thought to develop theological designs from the perspective of history, and thus of time (Van de Beek 1989):

A chronological relationship is the way we order events which are not logically or dialectically connected. A chronological ordering $[\ldots]$ is the only way in which a theology which bases itself on the deeds of God as criterion for its assertions can achieve results. (p. 261)

In Cobb's panentheistic model (Cobb \& Griffin 1977; Cobb 1965), this recourse to a paradigm, that is framed by time, is very clear: God is luring us to the future for new realisations of being which is also the fulfilment of God's own dynamic
Being. Those who focus more on counter powers that threaten humanity, see God's presence from the perspective of his combat with evil and the liberation of humankind. God sides with us in our struggle for a new world and when we despair, he initiates new courage. God is not controlling power, but empowerment for a better future. God is a 'God of progress, of possibility and of hope' (Gilkey 1976:300-318).

\section{God and history}

If we view God's involvement with the world from the perspective of history, the question arises whether he will finally overcome evil. 'Process theology', as developed by Whitehead and Cobb, is a consciously open system without an eschatological finalisation. Yet, due to its optimistic portrayal of progress by the accumulation of attained results, it is nevertheless a model of hope. One must wonder, however, how people who have lost the only one they loved, can be consoled by a universal perspective of a better world.

Therefore, most theologians opt for an eschatological fulfilment. They view history from the perspective of Revelation 21:4 (NIV): 'He will wipe every tear from their eyes.' We have to consider that this is not a mere epistemological revelation of the meaning of history. It could also fit into a doctrine of God as controlling power: finally we will understand what is now still hidden from us. It is much more an eschatological consummation of history when Christ will overcome all powers. Just like humanity, God is involved in a struggle that will only end in the eschatological event of God's final victory. For those who do not share the optimism of process theology and consider God's combat with evil as a real struggle, waiting for the eschatological victory can be a real tribulation. Though we can trust God's good intentions and are not hindered by the fear of a mysterium tremendum [overwhelming mystery] of controlling power, we are not sure about his power, for the future is principally open (Van de Beek 1986:121). Consequently, this model seems to make people uncertain, precisely in a context in which they search for consolation when attacked by bitter experiences. The benefit of this model over against a theology of God as controlling power and unfathomable fate might so be lost.

Therefore, most theologians who deal with God's intervention in history claim that he will indeed finally overcome. We can trust his victory. We can even trust God's power. This, however, is not controlling power, but eschatological power as Van Gennep states: 'God's omnipotence is an eschatological concept' (Van de Beek 2008:48; cf. Van Gennep 1989a:22; 1989b:425-427). Along these lines, König too develops his theology which he presents explicitly with a view to provide consolation. Jürgen Moltmann has elaborated this model extensively. Indeed, his whole oeuvre, beginning with Theologie der Hoffnung (Moltmann 1964), can be considered an elaboration of this theology of hope. In the power of the Spirit (Moltmann 1975), the triune God (Moltmann 1980) will bring his creation to its fulfilment in the eternal Sabbath (Moltmann 1985:281-299). 


\section{The future}

However, the question arises: how can we be certain that God will eventually overcome evil? In the model of the transcendent knowledge of God, this certainty is implied in the very definition of God: though we do not understand, he holds everything in his hand. In the eschatological model, however, God is involved in a struggle until the end of the world. Thus, what is gained in understanding, results in a loss of certainty. It is only in hope that we are saved.

Christian theologians will respond to this question by referring to the resurrection of Christ. Our hope is not unfounded. It is based on Christ's victory over death. In his resurrection as the crucified one, he not only overcame death, but all powers of evil and injustice.

Wolfhart Pannenberg has elaborated the relation of the resurrection of Christ and the final consummation of the world extensively. The resurrection is the prolepsis of the eschaton (Pannenberg 1991:393, 482; Pannenberg 1993:569-594; cf. Mostert 2002:112-116). In the resurrection of Christ, God showed that he is stronger than the powers of evil. Although they have ravaged history until now, we know that God is able to overcome them. Therefore our hope has solid ground. The final outcome of world history will be God's victory that is proclaimed and already proleptically effected when Christ rose from the dead.

A new question arises now. It is the old question that Orthodox Church fathers put to Marcion and the Gnostics: why does God wait so long? (Irenaeus IV.6.2; cf. Meijering 2001:95-97; 2008:30). The question to Marcion was about God's coming in Christ. If God is ultimate love by his coming in Christ, why did he come so late, leaving the world through all those preceding times in the hand of a perverse demiurge? The question to Pannenberg is: If God really possesses the power to overcome evil, why does he wait so long? Why does the consummation come so late? This question was already urgent at the end of the 1st century (2 Pt 3:9) and thus it should be much more urgent in the beginning of the 21st century.

Peter responds to this question by referring to God's patience. He gives people time to come to repentance (2 $\mathrm{Pt}$ 3:9). After 2000 years of church history, this answer has been rendered mute. Many people do not want to come to repentance, and due to the corrosion of history, the message of the church itself has lost its power and the fresh enthusiasm of its beginnings. If the Christianity of Paul and Peter could not convert the majority of people of their time, how will 21st century Christianity succeed?

Nevertheless, theologians hold on to the idea of time as an answer to the problem of evil. Oscar Cullmann used the metaphor of D-day and V-day (Cullmann 1946:72f.; cf. Beker 1980:177). On D-day the decisive battle was won. It would be only a matter of time until the final victory, V-day, over the Nazis would come. On Easter morning the decisive intervention of God has come. Now it is only a matter of time until the whole creation will be liberated.
This metaphor helps to understand why God's work takes time. However, it also displays the weakness of the eschatological model. If God is really able to overcome the powers, why does he need more than 2000 years? These are not neutral years, but a time of blood, sweat and tears, just like the time between D-day and V-day. It is a time in which the things König writes about happen, a time in which millions of people are killed and billions of people weep. If God is not able to intervene more effectively, does he then really posses the power? Was V-day absolutely certain after D-day? Could the Battle of the Bulge not have changed the whole outcome of World War II? Until the final victory, you never know.

Some theologians explicitly take the suffering of human history into account in connection with the final victory. It is the way God works: the way to glory is a way of suffering (Hall 1986; Moltmann 1972). They can build on strong scriptural evidence, for this is precisely the way of Christ. He rose from the dead after sufferings, injustice and death. Whosoever belongs to him will follow him on this path: 'In the world you will have trouble. But take heart! I have overcome the world' (Jn 16:33 NIV). However, as a theological model it evokes new questions. What kind of God is he who leads his people to glory through pain - not the chosen pain of a sportsperson in training, but the unchosen pain of wounded children in war? Is this God not a perverse God, like the god of the Gnostics, whom Irenaeus blamed that he gives humans pain in order to be honoured as Saviour? (Meijering 2001:95ff.). However, Irenaeus too, like all salvation-history theologians, fails to answer the question of why God brings people to the fulfilment through suffering (Meijering ibid:146-148). Does this God differ from the despised 'God of Calvin'?

\section{The eschatological model and the transcendence model}

The problems in the eschatological model are not fewer than those in the transcendence model. The questions about the benevolent will of God and about his power remain unanswered. These questions are not theoretical problems. They are the enigmas of life for human beings who suffer and weep. In both models they beg for God's intervention - not in the future and not by giving an indication why this suffering was necessary, but for the intervention of his liberating power here and now.

Both models leave us with similar questions that cut equally deep into the hearts of vulnerable human beings. Both try to provide comfort for these hearts. We can make a caricature of Calvin's God as an unfathomable mystery - a brute tyrant who acts arbitrarily. We can also make a caricature of Moltmann's hope when facing real world history. However, Calvin and his followers try to give rest to embattled souls (Hesselink 1997:111-117; Van den Belt 2008:107-109): they may know that their broken lives are in God's hand. This is not the hand of a tyrant, but of the Father of Jesus Christ, who gave his life on your behalf and shared your sufferings. The aim of Moltmann, Pannenberg, König and other adherents of 
the eschatological model is not different: in the ambiguities and even atrocities of history you may know that God's decisive battle against evil is over. Christ has overcome the evil powers that broke your lives and we can be sure of the consummation of this victory. Both answers try to strengthen Christians to persevere in faith.

Today the eschatological model is more acceptable than the transcendence model which was dominant during many preceding centuries. This is in accordance with the cultural shift that occurred with the rise of modernity. Before modernity, people could accept God's governance without understanding and co-responsibility. This is unacceptable in modernity. Human beings want to understand and they want to be involved. Human involvement implies time, and thus historical development. The eschatological model offers this required perspective. We turn our faces from heaven to the future. We can understand that history takes time and we can hope that one day everything will change for the better. Even more important is the idea that human beings can be involved in this change. We are involved in the coming of God's kingdom, whilst in the transcendence model we are ultimately dependent.

Human involvement as a decisive factor in God's final victory is, however, not a prerogative of modern theology. Origenes already says that a victory of God, which consists of mere physical repression, is not a true victory. God's final victory implies that he wins the hearts of his creatures and that they fully co-operate in his glory; they will no longer be enemies (Origenes Princ. I.6.1; III.6.5v). On the other hand, absolute dependence is a gift at the very moment that human beings are not able to act or to understand anymore. When the darkness of pain and suffering is too strong, we may know that God is stronger and that even this situation has not run out of his hand - though we do not understand it.

Both models have biblical roots. So there should be no reason to put them in opposition or even in conflict with each other. It is better either to conclude that theologians can develop different models for expressing God's relation to the world that is more complex than a simple model can express, or to develop a comprehensive model that includes both perspectives in a different paradigm. In the following sections some steps are taken to do the latter.

\section{Time and eternity}

So far we argued that references to God's transcendence or to his eschatological victory as an answer to the inequity of evil in creation do not differ very much. In both cases we are left with unanswered problems and both try to comfort people who are lost in despair.

We can also argue on a more profound systemic level that both responses do not differ. The transcendence model makes use of a spatial metaphor. The fact that God's government of our life is beyond our understanding, is interpreted from the idea that heaven is above the earth. Human beings live on earth and God is in heaven. 'As the heavens are higher than the earth, so are my ways higher than your ways and my thoughts than your thoughts', says the prophet Isaiah (Is 55:9 NIV). The eschatological model applies time as a metaphor: in the future God will overcome evil.

Theologians are usually very well aware that 'above' is metaphorical language. However, they often show less awareness that 'time' is also a metaphor. Eschatology is about the end of history and about the end of time. Anything beyond history is thus beyond time (Gilkey 1976:318). It follows therefore that we can only speak about eschatological time metaphorically just as we speak about heaven as 'above' metaphorically. Both concepts, that is time and space, are beyond earthly reality. They belong to what we call 'eternity'. Eternity is not endless time, but God's reality which is beyond time - or if one prefers: what is 'above' time. Both metaphors deal with the same reality. The one does so in terms of transcendence, and the other in terms of time and eschatological future. However, classic orthodox theology teaches that in eternity there is no time or space in the proper sense, as we apply these concepts to our own world. 'Eternity means that it has no beginning, no ending, and no sequence of time, that is: duration according to before and later, according to present, past and future' (Turrettini 1696 Institutio III.10.1; cf. Meijering 1991:113).

This implies that both models actually refer to the very same reality - to God's reality: one from the perspective of space and the other from the perspective of time. From the perspective of eternity they are one and the same and thus it does not matter which of the two we use. Calvin is not worse than König, and Leydecker must not be preferred to Moltmann. Which model we opt for fully depends on the effects that they have on human beings in a specific place and moment. Both are designed in order to give human beings consolation in suffering. The choice between the one and the other is not defined by eternity. Eternity leaves each approach open. Which one we apply depends fully on the human beings who live in space and time, in a specific space and at a specific time. We must carefully analyse their historical and cultural position in order to be able to give the right answer.

We cannot generalise the answer as if, for instance in view of the advent of modernity - we must always use the eschatological model. Not all people live synchronically. In fact, we can apply both metaphors to the same person on the same day if we proclaim the comfort of the gospel correctly. During the funeral service, a pastor can say to a mourning husband and his children: 'Mother is in heaven. We cannot cope with our sorrow, but God has given eternal happiness to her.' Half an hour later, at the graveside, the pastor says: 'This grave will be opened and she will arise in glory at the youngest day.' Nobody will object that the two proclamations are inconsistent. The intuition of faith understands that which troubles many theologians. The unity of eternal life is beyond inconsistencies and consistencies of time and space. 


\section{God's eternal council}

Augustine (Conf. XI.13) argued that time belongs to creation. He does so in order to respond to the question as to what God did before he created the world. Because time belongs to creation, there is no 'before' to creation. The same with eschatology: there is no 'after' to history. Modern physics claims that time and space belong intrinsically together: both belong to one and the same continuum. This implies that where there is no time, there is also no space. There is not an 'above' the earth and the stars. There is not an 'under' the earth there we will just see the stars of the very same universe.

The time-space-continuum in which we live, is like an island in the ocean of eternity. Maybe there are other universes with similar characteristics or with totally different properties; maybe with a kind of time that is not related to space, or space of a kind that is not connected to time. We do not know. We cannot but think in the categories of time and space. We cannot even distinguish whether this is a property of our mind or of the external world also, as Immanuel Kant argued.

So far, we dealt with transcendence and with time as an eschatological category and concluded that they concern one and the same reality: eternity. Now that we introduced Augustine, we can push the argument further: not only is time, as an eschatological category, a metaphor, but the same applies with regard to the beginning of creation. This metaphor - before the foundation of the world (Eph 1:4) - concerns the very same reality as transcendence and the eschaton, namely eternity which surrounds the universe of time and space. God's council before the foundation of the world is God's eternal council (cf. Heppe 1958:107-109). It is not a matter of time - of 'before' in a proper sense. The 'before' is just another metaphor for God's eternity, just like 'above', 'beyond' and 'after' are metaphors with regard to eternity in relation to the created world.

In eternity, God's eternal council and God's eternal judgment belong to one and the same reality and so, too, God's governance over human life and history. This is neither a reality of before and later nor a reality of here and yonder. It is the very same reality without time and without space. Thus, God's eternal council is not different from his final judgment and his final judgment has the very same content as his council. Both are the same as his governance, so that his guidance over world history does not lead away from his council. His judgment is identical with his will.

\section{God's benevolent will}

There is a risk that people consider the eternal council as a deterministic fate. World history is as it should be and nothing in God's eternal decisions can be changed. There is a risk that people consider God's governance as a capricious mystery that nobody can understand and must merely accept. Quietism, then, will be the best attitude of life. There is a risk that people consider God's final judgment as an act of revenge upon people who disobeyed his commandments - an act in which a wrathful God enjoys the pains of those who neglected him. World history can then become irrelevant and fatalistic in relation to eternity, and human beings seem as flies in the eyes of an omnipotent God. As a result, people can view themselves as flies whose capricious lives merely await the day that they will be crushed. Theological designs in modernity are usually sensitive to the aberrances of a theology of God's eternal council and a theology of his transcendent mysterious will. They are less sensitive to the aberrances of the eschatological model, because it is a model that provides hope - and maybe because we ourselves are involved. Precisely this latter aspect should make us more critical. If we consider what human beings are capable of, and learn from history, we should rather consider Dante's adage for hell: 'All hope abandon ye who enter here.' He who enters world history should know about blood, sweat and tears, and about the thorns and thistles of injustice and violence. Kant was right with his cynical remark to optimistic healers: 'I die of mere healing' (Kant 1798:93). History is much the same and improved technology will not result in improved morals. Those who designed the classic models of God's governance and his hidden will and who reflected on God's eternal council, would be just as sensitive to a modern theology of hope as the latter is sensitive to the idea of a hidden will.

\section{Only in the light of Christ}

We cannot deal with all these models as such. We cannot even deal with them as different approaches for responding to one and the same problem, namely that we cannot understand how the present world can be the world of a benevolent God. As such, they only point to a reality beyond our history and understanding. As such, they are an empty claim - both with regard to a real reference and to their content. That makes them a mysterium tremendum [overwhelming mystery] without any appeal, but filled with fear or even abhorrence.

Christian theology can only deal with these models if we learn from Scripture. In any of the models that we develop, we should always take into account that God is not a mere mystery, but that he has revealed himself in Christ. That is a revelation in time and space: 2000 years ago in Palestine. Christ is, however, the presence of the eternal God, the Name that is above every name (Phlp 2:9 NIV), the true God and eternal life (1 Jn 5:20 NIV). 'All things were created by him and for him' (Col 1:16). The Christ of history and time is before all things (Col 1:17). He is the hidden mystery that is beyond our time (Col 1:26).

If we speak about God's eternal council, then we must take into account what Ephesians says: 'He chose us in him from before the creation of the world' (Eph 1:4 NIV). The church father Irenaeus rejects the question: 'What did God do before he created the world?' (Adv. Haer. II.28.3). Trying to answer this question would be a blasphemous attempt to enter God's very being. Augustine answers that we cannot speak about 'before creation' in the proper sense (Conf. XI.13). However, even if we conceive 'before' as 'beyond' - as is included 
in both Irenaeus' and Augustine's answer - the question remains: How do we know about God's decisions that are beyond the present world, but that nevertheless define how this world runs? Without knowing God's transcendent will, we cannot understand the world in which we live.

\section{Before the world was founded}

The letter to the Ephesians answers the question what God did before he created the world: 'Before creation God chose us in Christ to be holy and blameless in his sight.' The 'before' may be improper, but the letter indicates that beyond this world we find God's benevolent will. The ocean that surrounds the universe of time and space is the ocean of God who loves the world. Therefore we may understand God's hidden will in his governance of the world as his will that he displays in the crucified Christ. If we speak about transcendence and being hidden, then human beings may know that their lives are hidden in Christ with God (Col 3:3). Thus we participate in his glory. Christian hope is the expression of the same reality from the perspective of time. We 'will appear with him in glory' (Col 3:4). According to the author of the letters to the Ephesians and the Colossians, everything is in Christ. He is before the creation, he is in heaven, and he will appear. The ultimate meaning of humans' lives is also in him: he chose them before creation, they are now hidden in him with God and they will appear with him in glory. He is the ultimate mystery of being (Col 1:26). So he is the answer to the question what width and length and height and depth is (Eph 3:20) the fundamental philosophical categories of being.

\section{Christ as the key to creation and history}

Other authors of the New Testament express this conviction each in their own way. Matthew begins his gospel with 'The book of the genesis of Jesus Christ' and again, after Jesus' genealogy, with 'the genesis of Jesus Christ' (Mt 1:18), referring to him as the fulfilment of creation, and he ends with Christ who proclaims: 'All authority in heaven and on earth has been given to me' (Mt 28:18). John begins with the Word through whom all things were created (Jn 1:1-3).

The Revelation of John deals explicitly with this issue. The book describes the disasters of world history in expressive pictures. World history is a chaos of powers, injustice, disasters and suffering in which no consistent meaning can be found. The book of Revelation indicates this with the image of a sealed book that nobody can open $(\operatorname{Rv} 5: 1-3)$. The meaning of history is concealed.

In this aporia it is proclaimed that the Lion of the tribe of Judah is found worthy to open the book ( $\operatorname{Rv} 5: 5)$. Only Christ can reveal the mystery of history and give meaning to its senseless chaos. When he appears before the visionary, the apostle sees a Lamb - as if it has been slain ( $\operatorname{Rv} 5: 6)$. This indicates that the meaning of history is only clear in this perspective. The meaning of history is found in a lamb that is slain. This is the paradigm for understanding what is going on in world history, in its communities and in the lives of human beings.
Without Christ, not only history, but any theological design will end in a dark mystery for those who evaluate it critically. In Christ we have hope - the hope of those who are crucified with him and who live in the temple of God; a temple not made by human hands, but the temple that is the body of Christ.

This approach gives a totally different view on what happens in the world. König's question 'God, waarom lyk die wêreld so?' ['God, why does the world look like this?'], which is the question of almost all people who think about suffering, is usually put from the presupposition that the world should not be as it is. It should be a world without suffering. In the perspective of the Lamb, however, suffering belongs to the world's very being. Suffering is not strange. It is normal. It is according to the norm of creation: the suffering Christ. In the introductory letters, the book Revelation expresses this with other words: Christ is the arche [origin, beginning, principle and ruler] of God's creation, and he is this as the faithful martus [witness] (Rv 3:14).

\section{Conclusion}

A christological approach of questions about God's governance implies that suffering should not be a problem in the theological discourse. This does not mean that suffering is no longer suffering. On the contrary, the very depth of suffering is revealed, because the suffering Christ, when dying, cries: 'My God, my God, why have you forsaken Me?' (Mk 15:34). All associations related to his death on the cross are included in these words. Suffering is extreme and hard, according to Scripture. It is not strange to created reality, however. According to the book of Revelation, the emblem of creation is a mortally wounded lamb with blood flowing from its body. That gives a different perspective on human suffering. It would be a challenge for Christian theologians to elaborate a discourse on suffering and God's governance in this paradigm. This would not be a totally new track. Early Christian writers can provide the material that is required for this enterprise.

\section{Acknowledgements Competing interests}

The author declares that he has no financial or personal relationship(s) that may have inappropriately influenced him in writing this article.

\section{References}

Augustine n.d., 'Confessiones', in J.P. Migne (ed.), Patrologia Latina, vol. 31, pp. 659-844. Beker, J.C., 1980, Paul the apostle: The triumph of God in life and thought, T\&T Clark, Edinburgh.

Blom, C., 2009, Zonder grond onder de voeten: Een theologische analyse van het boek Job en Genesis 1-4 vanuit het perspectief van het kwaad in de schepping, Boekencentrum Academic, Zoetermeer.

Calvin, J. n.d., Institutes, viewed 17 April 2013, from http://www.reformed.org/ master/index.html?mainframe=/books/institutes/

Cobb, J.B., 1965, A Christian natural theology. Based on the thought of Alfred North Whitehead, Westminster Press, Philadelphia.

Cobb, J.B. \& Griffin, D.R., 1977, Process theology: An introductory exposition, Westminster Press, Philadelphia.

Creeds of Christendom, 1561, Belgic Confession, viewed 17 April 2013, from http:// www.creeds.net/belgic/ 
Creeds of Christendom, 1563, Heidelberg Catechism, viewed 17 April 2013, from http:// www.creeds.net/reformed/Heidelberg/hdlb_int.htm

Cullmann, O., 1946, Christus und die Zeit: Die urchristliche Zeit- und Geschichts-auffassung, Evangelischer Verlag, Zürich.

Gilkey, L., 1976, Reaping the whirlwind: A Christian interpretation of history, Cross Road Book, Seabury Press, New York.

Hall, D.J., 1986, God and human suffering: An exercise in the theology of the cross, Augsburg Publishing House, Minneapolis.

Heppe, H., 1958, Die Dogmatik der evangelisch-reformierten Kirche, Neukirchener Verlag, Neukirchen.

Hesselink, I.J., 1997, Calvin's first catechism: A commentary, Westminster John Knox Press, Louisville, KY. (Columbia Series in Reformed Theology).

Hoek, P., 2013, 'Melchior Leydecker (1642-1721): Een onderzoek naar de structuur van de theologie van een gereformeerd scholasticus in het licht van zijn bronnen', Doctoral Dissertation Theology, VU University, Amsterdam.

Irenaeus, n.d., 'Adversus haereses', in J.P. Migne (ed.), Patrologia Graeca, vol. 7, pp. 437-1224.

Kant, I., 1798, 'Die Streit der Fakultäten', in G. Reimer (ed.), Kant's Werke, vol. 7, pp. 1-116, Königliche preussische Akademie der Wissenschaften, Berlin. (First published by G. Reimer in 1907).

König, A., 2002, God, waarom lyk die wêreld so?, Lux Verbi.BM, Wellington.

Kushner, H., 1981, When bad things happen to good people, Schocken Books, New York.

Leydecker, M., 1700, De Verborgentheid des geloofs, eenmaal den Heiligen overgelevert of het Kort Begryp der ware Godsgeleerdheid beleden in de Gereformeerde Kerk, Van Dyk, Rotterdam.

Meijering, E.P., 1991, Reformierte Scholastik und patristische Theologie: Die Bedeutung des Väterbeweises in der Institutio Theologiae Elencticae F. Turrettins unter besonderer Berücksichtigung der Gotteslehre und Christologie, De Graaf Publishers, Nieuwkoop. (Bibliotheca humanistica et reformatorica 50).

Meijering, E.P., 2001, Irenaeus: Grondlegger van het christelijk denken, Balans, Amsterdam.

Meijering, E.P., 2008, Klassieke gestalten van christelijk geloven en denken: Van Irenaeus tot Barth, Kok, Kampen.

Moltmann, J., 1964, Theologie der Hoffnung: Untersuchungen zur Begründung und zu den Konzequenzen einer christlichen Eschatologie, Kaiser, München. (Beiträge zur evangelischen Theologie 38).
Moltmann, J., 1972, Der gekreuzigte Gott: Das Kreuz Christi als Grund und Kritik christlicher Theologie, Kaiser, München.

Moltmann, J., 1975, Kirche in der Kraft des Geistes: Ein Beitrag zu Messianischen Ekklesiologie, Kaiser, München.

Moltmann, J., 1980, Trinität und Reich Gottes:Zur Gotteslehre, Kaiser, München.

Moltmann, J., 1985, Gott in der Schöpfung: Ökologische Schöpfungslehre, Kaiser, München.

Mostert, C., 2002, God and the future: Wolfhart Pannenberg's eschatological doctrine of God, T\&T Clark, London/New York.

Origenes n.d., De Principiis, in J.P. Migne (ed.), Patrologia Graeca, vol. 11, pp. 11-414.

Pannenberg, W.A., 1991, Systematische Theologie, vol. 2, Vandenhoeck \& Ruprecht, Göttingen.

Pannenberg, W.A., 1993, Systematische Theologie, vol. 3, Vandenhoeck \& Ruprecht, Göttingen.

Singghi, G., 2012, 'An alternative creation belief', in E. Van der Borght \& P. van Geest (eds.), Strangers and pelgrims on earth: Essays in honour of Abraham van de Beek, pp. 683-696, Brill, Leiden/Boston. (Studies in Reformed Theology 22).

Turrettini, F., 1696, Institutio Theologiae Elencticae in qua status controversiae perspicue exponitur, praecipua orthodoxorum argumenta proponuntur \& vindicantur, \& fontes solutionum aperiuntur, Haring, Leiden/Voskuyl, Utrecht.

Van de Beek, A., 1986, 'Om de levende God', in J.P. Heering et al. (eds.), Nogmaals Waarom? Artikelen over en reakties op het gelijknamige boek van dr. A. van de Beek over lijden, schuld en God, pp. 105-123, Callenbach, Nijkerk.

Van de Beek, A., 1989, Why? On suffering, guilt, and God, Eerdmans, Grand Rapids.

Van de Beek, A., 2008, God doet recht: Eschatologie als christologie, Meinema, Zoetermeer.

Van den Belt, H., 2008, The authority of Scripture in Reformed theology: Truth and trust, Brill, Leiden/Boston. (Studies in Reformed Theology 17).

Van den Brink, G. \& Van der Kooi, C., 2012, Christelijke dogmatiek: Een inleiding, Boekencentrum, Zoetermeer.

Van Genderen, J. \& Velema, W.H., 1992, Beknopte Gereformeerde dogmatiek, Kok, Kampen.

Van Gennep, F.O., 1989a, 'Het is beslist', in F.O. van Gennep et al. (eds.), Waarlijk opgestaan! Een discussie over de opstanding van Jezus Christus, pp. 9-23, Ten Have, Baarn.

Van Gennep, F.O., 1989b, De terugkeer van de verloren vader: een theologisch essay over vaderschap en macht, Ten Have, Baarn. 